\title{
Caring Climate, Komitmen Organisasi, Dan Kepuasan Kerja
}

\author{
Yunus Ardian Priliyanto \\ Universitas Katolik Soegijapranata Semarang \\ ardiantm@gmail.com \\ Monika Palupi Murniati \\ Universitas Katolik Soegijapranata Semarang \\ palupi@unika.ac.id
}

\begin{abstract}
This study aims to analyze the effect of caring climate on employee performance by mediating variable job satisfaction and organizational commitment according to gender proportions. Caring climate is a way for people to make decisions that prioritize the welfare of all people. The sample of this study was 96 employees of Soegijapranata Catholic University Semarang. Fit test is conducted to find out whether the research model meets the structural equation model assumptions or not, the data is said to be fit after deleting 10 data, so that the remaining 86 sample data. This study uses SEM (Structural Equation Modeling) with the AMOS program. The results of this study are that Caring climate influences organizational commitment through the mediating role of job satisfaction, Caring climate influences employee performance through the mediating role of job satisfaction, but Caring climate does not affect employee performance through the mediating role of organizational commitment, Job satisfaction does not affect employee performance through the mediating role of organizational commitment, and Gender becomes a differentiator in the perception of male and female respondents towards caring climate, employee performance, job satisfaction and organizational commitment.
\end{abstract}

Keywords: caring climate, job satisfaction, organizational commitment, job performance, gender

Abstrak
Penelitian ini bertujuan untuk menganalisis pengaruh caring climate terhadap kinerja karyawan dengan mediasi variabel kepuasan kerja dan komitmen organisasi menurut proporsi gender. Caring climate merupakan cara orang dalam mengambil keputusan yang mengutamakan kesejahteraan semua orang. Sampel penelitian ini adalah 96 karyawan Universitas Katolik Soegijapranata Semarang. Uji fit dilakukan pertama untuk mengetahui model penelitian memenuhi asumsi model persamaan struktural atau tidak, data dikatakan fit setelah menghapus 10 data, sehingga tersisa 86 data sampel. Penelitian ini menggunakan SEM (Structural Equation Modelling) dengan program AMOS. Hasil penelitian ini adalah Caring climate berpengaruh terhadap komitmen organisasi melalui peran mediasi kepuasan kerja, Caring climate berpengaruh terhadap kinerja karyawan melalui peran mediasi kepuasan kerja, tetapi Caring climate tidak berpengaruh terhadap kinerja karyawan melalui peran mediasi komitmen organisasi, Kepuasan kerja tidak berpengaruh terhadap kinerja karyawan melalui peran mediasi komitmen organisasi, dan Gender menjadi pembeda persepsi responden laki-laki dan perempuan terhadap caring climate, kinerja karyawan, kepuasan kerja dan komitmen organisasi.

Kata kunci: caring climate, kepuasan kerja, komitmen organisasi, kinerja karyawan, Gender. 


\section{PENDAhUluan}

Salah satu hal yang paling sering menjadi masalah dalam organisasi adalah sumber daya, dimana hal yang paling penting yaitu mengenai sumber daya manusia. SDM yang berperan sebagai penggerak dalam sebuah organisasi tentu sangat penting untuk dilakukan penilaian. Kinerja menurut Melina dan Ratnawati (2012) merupakan tingkat keberhasilan karyawan dalam melaksanakan tugas dan tanggung jawabnya.

Penilaian kinerja perlu dilakukan untuk mengetahui seberapa efektif dan efisien SDM yang dimiliki oleh organisasi dalam mencapai tujuannya. Sepanjang organisasi berdiri penilaian kinerja sangat perlu dilakukan, karena hal tersebut juga menjadi dasar organisasi dalam melakukan evaluasi kinerja. Manfaat penilaian kinerja karyawan yang dilakukan secara objektif, tepat dan didokumentasikan secara baik cenderung menurun potensi penyimpangan yang dilakukan karyawan, sehingga kinerjanya diharapkan harus bertambah baik sesuai dengan kinerja yang dibutuhkan perusahaan (Murty dan Hudiwinarsih 2012).

Selain itu Caring climate berfokus pada kebajikan etis kriteria dan didasarkan pada kepedulian terhadap orang lain Fu dan Deshpande (2014). Berdasarkan pengertian diatas caring climate merupakan cara orang dalam mengambil keputusan yang mengutamakan kesejahteraan semua orang. Hal ini membuat carring climate penting dalam perusahaan karena dengan keputusan yang menyejahterakan semua orang, tentu akan mempengaruhi kinerja karyawan dalam perusahaan. Dengan adanya carring climate juga akan menciptakan lingkungan kerja atau suasana kerja yang membuat karyawan menjadi nyaman dan ingin tetap bekerja di organisasi tersebut.

Pada penelitian yang dilakukan oleh Fu dan Deshpande (2014) penelitian mengenai kinerja karyawan yang dipengaruhi oleh caring climate, kepuasan kinerja, dan komitmen organisasi. Penelitian ini menggunakan pemodelan persamaan struktural (SEM) untuk menguji hubungan langsung dan tidak langsung caring climate, kepuasan kerja, komitmen organisasi, dan kinerja karyawan dari 476 karyawan bekerja di perusahaan asuransi Cina. Riset ini menggunakan sampel yang terdiri dari $43,7 \%$ responden laki-laki dan 56,3\% responden adalah perempuan. Fu dan Deshpande, 2014 melakukan penelitian karena terdapat beberapa tindakan tidak etis yang di lakukan pekerja dalam proses mencari konsumen. Seperti taktik penjualan yang menyesatkan, dan penipuan.

Keterbatasan riset $\mathrm{Fu}$ dan Deshpande (2014) karena sampel terdiri dari $43,7 \%$ responden laki-laki dan 56,3\% responden adalah perempuan. Hal ini diusulkan oleh Fu dan Deshpande (2014) karena ada lebih banyak pekerja wanita dari pekerja laki-laki di perusahaan sampel dan sebagian besar responden memiliki gelar sarjana, hasilnya mungkin berbeda dalam perusahaan yang memiliki karakteristik karyawan yang berbeda dari perusahaan sampel. Hasil dari penelitian tersebut menunjukkan bahwa caring climate memiliki pengaruh langsung yang signifikan pada kepuasan kerja, komitmen organisasi, dan kinerja karyawan. Caring climate juga memiliki pengaruh signifikan pada komitmen organisasi melalui peran mediasi kepuasan kerja, dan kinerja karyawan melalui peran mediasi kepuasan kerja dan komitmen organisasi. Selain itu, kepuasan kerja berpengaruh signifikan terhadap komitmen organisasi, namun kepuasan kerja tidak berpengaruh signifikan pada kinerja karyawan. Akhirnya, komitmen organisasi berdampak langsung yang signifikan terhadap kinerja karyawan.

Pengaruh ethical climate terhadap kinerja memiliki pengaruh melalui komitmen organisasi (Fu dan Deshpande 2014). Sebagai tambahan, penelitian lain juga menunjukkan bahwa ethical climate dapat mempengaruhi kepuasan kerja, dan komitmen berorganisasi (Jaramillo et al. 2017). Penelitian mengenai caring climate, kepuasan kerja dan komitmen organisasi pada pekerjaan kinerja masih sangat sedikit. 
Sex role stereotypes terkait dengan anggapan umum, bahwa laki-laki itu lebih berorientasi pada pekerjaan, obyektif, independen, agresif, dan pada umumnya mempunyai kemampuan lebih dibandingkan perempuan dalam pertanggung jawaban manajerial. Disisi lain perempuan dipandang lebih pasif, lembut, orientasi pada pertimbangan, lebih sensitif dan lebih rendah posisinya pada pertanggung jawaban dalam organisasi dibandingkan laki-laki. Berdasarkan dari adanya perbedaan karakter tersebut maka ada kemungkinan bahwa kinerja karyawan antara laki-laki dan perempuan memiliki perbedaan. Sehingga saran Fu dan Deshpande (2014) untuk meneliti kembali dengan proporsi gender yang berbeda menjadi penting.

Dari penjelasan perbedaan antara karakter perempuan dan laki-laki dapat disimpulkan bahwa dengan perbedaan karakter yang bahkan hampir berlawan, tentu saja hal ini mungkin berpengaruh pada kinerja karyawan. Efek yang ditimbulkan akibat perbedaan karakter tersebut antara lain; perempuan lebih teliti dan akurat dibandingkan laki-laki. Hal ini mungkin berdampak dalam kinerja nya yang mana perempuan memiliki kerja lebih baik dalam hal ketelitian dan keakuratan. Di lain sisi, laki-laki yang memiliki karakter ceroboh tentu akan memiliki kinerja yang buruk khususnya dalam hal yang berhubungan dengan pencatatan dan administrasi karena kurang teliti dan ceroboh. Selain itu, karakter perempuan yang lebih lembut dan emosional dapat meningkatkan nilai carring climate yang ditimbulkan oleh karyawan perempuan, dibandingkan karyawan laki-laki yang tidak secara penuh dapat menyerahkan diri kelingkungannya.

Dalam industri pendidikan memiliki sistem organisasi yang berbeda dengan industri asuransi. Industri pendidikan memiliki sistem organisasi yang bersifat kolegial, dimana atasan dan bawahan dapat bertukar posisi. Sistem organisasi kolegial membuat setiap karyawan memiliki kedekatan dengan rekan kerjanya dan saling peduli dalam organisasi nya. Dalam pembuatan keputusan setiap karyawan bermusyawarah terlebih dahulu sebelum keputusan tersebut di ambil. Serta aktivitas dan pengembangan kemampuan individual terjadi karena adanya interaksi di dalam organisasi. Hal ini membuat caring cimate mempunyai peran yang penting. Selain itu Universitas Katolik Soegijapranata memiliki budaya religius agama Katolik yang begitu dekat dengan organisasi. Oleh karena itu saya ingin mengetahui bagaimana caring climate yang ada di industri pendidikan yaitu di Universitas Katolik Soegijapranata.

Berdasarkan keterbatasan pada penelitian sebelumnya lebih banyak responden perempuan sehingga saya ingin melakukan penelitian dengan respoden laki-laki yang lebih banyak. Selain itu Universitas Katolik Soegijapranata memiliki budaya religius agama Katolik yang dekat dengan organisasi. Oleh karena itu saya ingin mengetahui bagaimana caring climate yang ada di industri pendidikan yaitu di Universitas Katolik Soegijapranata.

\section{TINJAUAN LITERATUR DAN PERUMUSAN HIPOTESIS}

\section{Kinerja karyawan}

Melina dan Ratnawati (2012) Kinerja merupakan hasil kerja secara kualitas maupun kuantitas yang dicapai oleh seseorang dalam melaksanakan tugas yang diberikan kepadanya sesuai dengan standar atau kriteria yang telah ditetapkan. Kinerja karyawan menunjukan seberapa berhasil karyawan dapat menyelesaikan tugas dan tanggung jawab yang di berikan ke mereka untuk di selesaikan. Semakin tinggi kinerja karyawan, maka semakin baik karyawan tersebut dalam menjalankan tanggung jawabnya sehingga berdampak baik untuk organisasi.

Ristadewi (2011) Menemukan penilaian kinerja adalah suatu sistem formal dan terstruktur yang mengukur, menilai, dan mempengaruhi sifat-sifat yang berkaitan dengan pekerjaan, perilaku, dan hasil, termasuk tingkat ketidakhadiran. Penilaian kinerja tersebut 
akan menjadi bahan pertimbangan bagi perusahaan untuk melakukan pergantian karyawan berdasarkan kinerja mereka terhadap perusahaan. Keahlian teknis meliputi penilaian karyawan terhadap kemampuannya untuk bekerja dengan akurat, hati-hati, dan konsiten; ketepatan waktu dalam menyelesaikan pekerjaan; pemahamannya terhadap esensi pekerjaan yang dilakukannya; adanya tanggung jawab atas pekerjaan yang dilakukannya. Keahlian interpersonal meliputi penilaian karyawan terhadap kemampuannya bekerja sama dalam tim.

Berdasarkan pernyataan diatas, penilaian kinerja karyawan adalah sesuatu proses penilaian prestasi kerja karyawan yang dilakukan oleh pimpinan perusahaan secara sistematis berdasarkan pekerjaan yang ditugaskan kepadanya. Selain itu kepala bagian personalia berhak pula memberikan penilaian kinerja terhadap semua karyawannya sesuai dengan data yang ada di bagian personalia. Karyawan juga dapat memprediksi seberapa besar kinerja pada perusahaan atau organisasi dengan faktor-faktor pembentuk kinerja yaitu faktor kemampuan (ability) dan faktor motivasi pada diri mereka sendiri.

Hal ini akan sangat membantu parusahaan untuk menentukan pergantian karyawan yang di nilai berdasarkan kinerja mereka. Perusahaan juga akan lebih mudah memberikan bonus terhadap karyawan yang memiliki kinerja di atas rata-rata yang berguna meningkatkan motivasi karyawan untuk berkerja lebih baik lagi bagi perusahaan dan selalu memenuhi target yang di berikan perusahaan. Jadi dengan dilakukan penilaian kinerja akan didapat informasi mengenai kinerja pegawai dimasa lalu dan gambaran kinerja dimasa yang akan datang,serta bagaimana meningkatkan kinerja agar lebih baik dari sebelumnya.

\section{Gender}

Pada pengertian Sex role stereotypes terkait dengan anggapan umum, bahwa laki-laki itu lebih berorientasi pada pekerjaan, obyektif, independen, agresif, dan pada umumnya mempunyai kemampuan lebih dibandingkan perempuan dalam pertanggung jawaban manajerial. Disisi lain perempuan dipandang lebih pasif, lembut, orientasi pada pertimbangan, lebih sensitif dan lebih rendah posisinya pada pertanggung jawaban dalam organisasi dibandingkan laki-laki. Perkembangan moral dan cara berfiikir antara perempuan dan laki-laki memang memiliki perbedaan secara umum. Pengaruh perbedaan gender tersebut akan berpengaruh pada pengambilan keputusan, karena laki-laki dan perempuan memiliki perbedaan karakteristik serta memiliki kepribadian yang berbeda juga.

Kartono (1992) menjelaskan perbedaan gender dalam pengambilan keputusan. Karakteristik laki-laki dan perempuan cenderung berbeda, bahkan berlawanan. Hal ini jelas membuat beberapa tindakan atau kinerja mereka dalam organisasi akan berbeda. Contoh tindakan yang mungkin akan berbeda adalah pemilihan bagian dalam pekerjaan yang mana perempuan lebih suka bekerja menggunakan emosional dan pekerjaan yang banyak menggunakan perasaan seperti bidan, guru, dan pekerja seni. Sedangkan laki-laki yang tidak terlalu banyak menggunakan emosional dalam pekerjaan lebih dapat bekerja di semua bidang, mulai dari politik, ekonomi. Dari cara pandang dan karakteristik yang berbeda dapat di simpulkan bahwa kinerja kedua nya juga memiliki perbedaan.

\section{Caring climate}

Ethical climate adalah jenis iklim kerja yang memandu perilaku etis dalam suatu organisasi (Fu dan Deshpande, 2014). Mereka membantu karyawan memutuskan perilaku yang benar atau salah dalam diri mereka di organisasi. Dengan adanya ethical climate perilaku karyawan menjadi lebih terarah dalam membuat keputusan dan akan meminimalkan kesalahan yang mungkin terjadi. Huang et al. (2012)menjelaskan keenam tipe iklim dan uraiannya adalah sebagai berikut: Profesionalisme (orang diharapkan untuk mematuhi hukum dan standar profesional), caring (pertimbangan utama kami adalah apa terbaik untuk semua 
orang di organisasi), aturan (setiap orang diharapkan untuk tetap oleh organisasi aturan dan prosedur), instrumental (dalam organisasi ini, orang melindungi kepentingan mereka sendiri di atas semuanya), efisiensi (cara yang paling efisien adalah cara yang benar dalam organisasi ini), independensi (setiap orang dalam organisasi ini memutuskan untuk sendiri apa yang benar dan salah).

Fu dan Deshpande (2014) menjelaskan bahwa Caring climate berfokus pada kebajikan etis kriteria dan didasarkan pada kepedulian terhadap orang lain. Berdasarkan pengertian diatas caring climate merupakan cara orang dalam mengambil keputusan yang mengutamakan kesejahteraan semua orang. Hal ini membuat caring climate penting dalam perusahaan karena dengan keputusan yang menyejahterakan semua orang, tentu akan mempengaruhi kinerja karyawan dalam perusahaan. Dengan adanya carring climate juga akan menciptakan lingkungan kerja atau suasana kerja yang membuat karyawan menjadi nyaman dan ingin tetap bekerja di organisasi tersebut.

\section{Kepuasan kerja}

Kepuasan kerja termasuk dalam hal yang penting dalam organisasi. Kepuasan kerja memiliki dampak terhadap perilaku kerja seperti malas, rajin, produktif, dll atau mempunyai hubungan dengan beberapa jenis perilaku yang sangat penting dalam organisasi. Situasi kerja yang menyenangkan dapat terbentuk apabila sifat dan jenis pekerjaan yang harus dilakukan sesuai dengan kebutuhan dan nilai yang dimiliki oleh karyawan.

Kepuasan kerja karyawan merupakan masalah penting yang diperhatikan dalam hubungannya dengan produktivitas kerja karyawan dan ketidakpuasan sering dikaitkan dengan tingkat tuntutan dan keluhan pekerjaan yang tinggi. Pekerja dengan tingkat ketidakpuasan yang tinggi lebih mungkin untuk melakukan sabotase Tania dan Sutanto (2013). Indikator kepuasan kerja biasanya diukur dengan tingkat turnover karyawan dan absensi. Tingkat turnover karyawan dan absensi kecil maka relatif kepuasan kerja karyawan baik. Sebaliknya jika tingkat turnover karyawan dan absensi besar, maka kepuasan kerja diperusahaan kurang baik. Selain itu, umur dan jenjang pendidikan juga memiliki korelasi dengan kepuasan kerja. Semakin tua karyawan,biasanya mereka semakin terpuaskan dengan pekerjaan mereka. Sebaliknya karyawan yang lebih muda cenderung kurang terpuaskan karena harapan-harapan yang tinggi tidak dapat terwujud, kurang penyesuaian dan sebagainya. Begitu juga dengan jenjang pekerjaan, bagi karyawan yang memiliki jenjang pekerjaan yang semakin tinggi akan memperoleh kepuasan kerja lebih baik dari sebelumnya. Mereka yang jenjang pekerjaannya lebih atau semakin tinggi, biasanya memperoleh kompensasi yang lebih baik, kondisi kerja lebih nyaman dan sebagainya.

Secara definisi, kepuasan kerja merupakan sikap positif karyawan terhadap pekerjaannya, yang timbul berdasarkan penilaian terhadap situasi kerja Melina dan Ratnawati, (2012). Dari beberapa pendapat diatas maka dapat disimpulkan bahwa kepuasan kerja adalah keadaan emosional seseorang yang bisa terlihat melalui tingkah laku, dan sikap baik yang menyenangkan atau tidak menyenangkan terhadap pekerjaan yang mereka lakukan.

\section{Komitmen organisasi}

Anggota organisasi yang berkomitmen terhadap organisasinya mungkin saja mengembangkan pola pandang yang lebih positif terhadap organisasi dan dengan senang hati tanpa paksaan mengeluarkan energi ekstra demi kepentingan organisasi Melina dan Ratnawati (2012). Komitmen organisasional adalah ukuran karyawan identifikasi dengan organisasinya. Komitmen pada organisasi yang tinggi berarti pemihakan pada organisasi yang mempekerjakannya. Komitmen manajer pada organisasi merupakan salah satu sikap yang mencerminkan perasaan suka atau tidak suka seorang manajer terhadap organisasi tempat dia bekerja. Komitmen organisasional menunjukkan suatu daya dari dalam diri 
seseorang dalam mengidentifikasi keterlibatannya dalam suatu organisasi.Hubungan ini secara signifikan dapat menjelaskan perilaku individu dalam organisasi.

Komitmen organisasional didefinisikan sebagai kekuatan yang bersifat relatif dari individu dalam mengidentifikasikan keterlibatan dirinya kedalam bagian organisasi, yang dicirikan oleh penerimaan nilai dan tujuan organisasi, kesediaan berusaha demi organisasi dan keinginan mempertahankan keanggotaan dalam organisasi (Tania dan Sutanto 2013). Hal tersebut menunjukkan bahwa komitmen organisasional memiliki arti yang lebih dari sekedar loyalitas yang pasif, tetapi melibatkan hubungan aktif dan keinginan karyawan untuk memberikan kontribusi yang berarti pada organisasinya baik secara langsung maupun tidak langsung yang dapat membuat organisasi tersebut menjadi lebih baik atau menyelesaikan target yang telah ditetapkan sebelumnya.

Komitmen organisasi baik dari karyawan terhadap organisasi atau dari organisasi terhadap karyawan, sangat di perlukan guna menciptakan lingkungan kerja yang profesional. Karyawan yang memiliki komitmen organisasi yang tinggi tentu akan lebih memiliki rasa loyalitas dan tanggung jawab terhadap organisasinya. Sehingga dalam menjalankan pekerjaan dia akan lebih maksimal dan tidak merasa terbebani dengan target organisasi. Sebaliknya bagi karyawan yang memiliki komitmen organisasi yang rendah lebih banyak melakukan kegiatan yang dapat menganggu organisasi tersebut, seperti melakukan pekerjaan dengan lamban, sering mengeluh, bahkan melakukan mogok kerja.

\section{Caring climate, Komitmen Organisasi dan Kepuasan Kerja}

Caring climate dalam penelitian ini memiliki arti persepsi responden mengenai pertimbangan kesejahteraan untuk setiap orang dalam organisasi yang digunakan saat membuat keputusan. Dengan mempertimbangkan kesejahteraan untuk orang lain saat mengambil keputusan di organisasi, hal ini akan membuat setiap karyawan saling peduli dan memperhatikan dalam lingkungan kerjanya. Akan saling menolong dalam menjalankan tugas serta akan saling mendukung saat bekerja.

Kepuasan kerja merupakan sikap positif karyawan terhadap pekerjaannya, yang timbul berdasarkan penilaian terhadap situasi kerja. Dalam penelitian ini kepuasan kerja berarti persepsi responden mengenai untuk tetap bekerja dan kepuasan terhadap pekerjaannya. Perasaan responden mengenai seberapa besar keinginannya untuk berhenti dari pekerjaannya saat ini, dan perasaannya mengenai seberapa puas dengan pekerjaan yang saat ini dia lakukan. Pekerjaan yang setiap hari dia lakukan dan kerjakan. Dan keinginan responden untuk tetap bekerja di organisasi tersebut.

Komitmen organisasi dalam penelitian ini adalah persepsi responden mengenai keterikatannya dan ketergantungannya dengan organisasi. Dengan adanya sifat ketergantungan dari karyawan terhadap organisasi serta keterikatannya. Hal ini akan membuat karyawan selalu melakukan yang terbaik untuk organisasi. Karena dengan adanya sifat ketergantungan apabila organisasi mengalami masalah maka karyawan juga akan mendapat masalah yang sama. Serta karena karyawan memiliki keterikan terhadap organisasi maka dia akan berusaha sebaik mungkin untuk membuat organisasi yang stabil dan nyaman untuk dia bekerja.

Suasana kerja atau lingkungan kerja yang saling peduli antar karyawan, serta keinginan dari masing-masing karyawan untuk membantu rekan kerja mereka. Menciptakan lingkungan kerja yang nyaman. Dengan lingkungan kerja mereka saling mendukung dan tidak hanya mementingkan diri sendiri. Mereka akan puas terhadap kinerjanya, sehingga karyawan akan merasa puas dengan pekerjaan yang telah dilakukannya dan selalu ingin berkerja di lingkungan kerja tersebut.

Saat seseorang sudah merasa puas akan apa yang di dapatnya dari organisasi. Serta semua kebutuhannya sudah tercukupi di organisasi tersebut. Karyawan tersebut merasa tidak 
ingin meninggalkan organisasi tersebut dan selalu ingin berada di organisasi tersebut. Dapat di artikan bahwa karyawan tersebut memiliki kepuasan terhadap pekerjaannya. Yang membuat mereka merasa ingin tetap bekerja di organisasi ini dan menciptakan ikatan antara karyawan terhadap organisainya. Karyawan mendapatkan hal yang dia inginkan dari organisasi tersebut. Perasaan puas juga akan meningkatkan ketergantungan antara karyawan terhadap organisasinya.

Hal ini di dukung dengan penelitian dari; Okpara dan Wynn, (2012) studi mereka di Nigeria menemukan bahwa caring climate memiliki dampak positif yang signifikan terhadap kepuasan kerja secara keseluruhan dan berbagai aspek kepuasan kerja termasuk promosi, pengawasan, rekan kerja, dan bekerja sendiri. (Tania dan Sutanto, 2013) Menunjukkan bahwa kepuasan kerja akan mampu meningkatkan komitmen organisasional.

Berdasarkan pemikiran diatas, maka hipotesis satu dirumuskan sebagai berikut:

\section{$\mathrm{H}_{1}$ : Caring climate memiliki pengaruh yang signifikan terhadap komitmen organisasi melalui peran mediasi kepuasan kerja.}

\section{Caring climate, Kinerja Karyawan, dan Kepuasan Kerja}

Caring climate memiliki arti persepsi responden mengenai mempertimbangan kesejahteraan untuk setiap orang dalam organisasi yang digunakan saat membuat keputusan. Saat seseorang mempertimbangkan kesejahteraan orang lain ketika mengambil keputusan di organisasi, akan menciptakan lingkungan kerja antar karyawan yang saling peduli dan memperhatikan di tempat kerjanya. Dan saling menolong dalam menjalankan tugas serta akan saling mendukung saat bekerja.

Kepuasan kerja berarti sikap karyawan terhadap pekerjaannya, yang timbul berdasarkan penilaian terhadap situasi kerja. Kepuasan kerja merupakan persepsi responden mengenai keinginan untuk tetap bekerja dan kepuasan terhadap pekerjaan yang saat ini sedang di lakukan. Emosional responden mengenai seberapa besar keinginannya untuk berhenti dari pekerjaannya saat ini, dan perasaannya mengenai seberapa puas dengan pekerjaan yang saat ini dia lakukan.

Selain itu terdapat kinerja karyawan yang merupakan hasil kerja secara kualitas maupun kuantitas yang dicapai oleh seseorang dalam melaksanakan tugas yang diberikan kepadanya sesuai dengan standar atau kriteria yang telah ditetapkan. Dimana kinerja ini yang akan menjadi tolak ukur bagi orgnanisasi dalam menilai karyawannya. Dalam penelitian ini persepsi responden mengenai seberapa baik hasil penilaian kinerja menurut responden, menurut hasil penilaian kinerja oleh atasan dan oleh rekan kerja.

Dengan adanya lingkungan kerja yang saling peduli dan saling mendukung antara karyawan. Serta keinginan karyawan dalam membuat keputusan yang mempertimbangkan kesejahteraan orang lain. Akan membuat karyawan merasa puas dengan pekerjaannya dan organisasinya. Hal ini menjadikan karyawan merasa ingin untuk tetap bekerja di organisasi tersebut. Dan puas dengan lingkungan kerjanya yang saat ini.

Karyawan yang merasa puas dengan pekerjaannya dan keinginan mereka untuk tetap bekerja di organisasi tersebut. Menciptakan perasaan cinta terhadap pekerjaan mereka. Sehingga mereka akan melakukan pekerjaan dengan sepenuh hati dan totalitas. Hal ini akan meningkatkan semangat karyawan dalam bekerja serta menyelesaikan pekerjaan mereka. Perasaan tersebut membuat kinerja karyawan menjadi tinggi dalam pekerjaan mereka dan akan lebih semangat untuk mencapai target kerja mereka karena rasa totalitas dan keinginan untuk tetap bekerja di organisasi tersebut. Jadi semakin terpuaskan karyawan, maka karyawan akan semakin menunjukkan kinerja terbaiknya. Sebaliknya, jika karyawan tidak merasa puas dalam bekerja, maka dalam dirinya akan timbul rasa malas, sehingga akan berdampak pada menurunnya kinerja. 
Penelitian Okpara dan Wynn (2012) menemukan bahwa caring climate memiliki dampak positif yang signifikan terhadap kepuasan kerja secara keseluruhan dan berbagai aspek kepuasan kerja termasuk promosi, pengawasan, rekan kerja, dan bekerja sendiri. Menemukan bahwa responden yang percaya bahwa organisasi mereka memiliki caring climate lebih puas dengan pengawas mereka dalam survei terhadap 252 manajer tingkat menengah dari sebuah organisasi nirlaba.

Selain itu penelitan Indrawati (2013) Menemukan hubungan positif yang signifikan secara statistik antara kepuasan dan kinerja. Selain itu ada hubungan positif antara kepuasan kerja dan kinerja dalam survei terhadap 335 responden yang bekerja di sektor perbankan tingkat menengah (Aftab dan Idrees ,2012).

Berdasarkan pemikiran diatas, maka hubungan Caring climate, kinerja karyawan, dan kepuasan kerja dapat dirumuskan dalam hipotesis berikut:

\section{$\mathrm{H}_{2 \mathrm{a}}$ : Caring climate memiliki pengaruh yang signifikan terhadap kinerja karyawan melalui peran mediasi kepuasan kerja.}

Caring climate memiliki arti persepsi responden mengenai mempertimbangan kesejahteraan untuk setiap orang dalam organisasi yang digunakan saat membuat keputusan. Saat seseorang mempertimbangkan kesejahteraan orang lain ketika mengambil keputusan di organisasi, akan menciptakan lingkungan kerja antar karyawan yang saling peduli dan memperhatikan di tempat kerjanya. Dan saling menolong dalam menjalankan tugas serta akan saling mendukung saat bekerja.

Komitmen organisasi dalam riset ini adalah persepsi responden mengenai keterikatannya dan ketergantungannya dengan organisasi. Dengan adanya sifat ketergantungan dari karyawan terhadap organisasi serta keterikatannya. Hal ini akan membuat karyawan selalu melakukan yang terbaik untuk organisasi. Karena karyawan menggantung hidupnya kepada organisasi, dimana saat organisasi tersebut sedang berada dalam masalah karyawan tersebut juga akan mendapat masalah. Karyawan yang memiliki komitmen organisasi yang tinggi tentu akan lebih memiliki rasa loyalitas dan tanggung jawab terhadap organisasinya.

Sedangkan kinerja karyawan yang merupakan hasil kerja secara kualitas maupun kuantitas yang dicapai oleh seseorang dalam melaksanakan tugas yang diberikan kepadanya sesuai dengan standar atau kriteria yang telah ditetapkan. Dimana kinerja ini yang akan menjadi tolak ukur bagi orgnanisasi dalam menilai karyawannya. Dalam penelitian ini persepsi responden mengenai seberapa baik hasil penilaian kinerja menurut responden, menurut hasil penilaian kinerja oleh atasan dan oleh rekan kerja.

Lingkungan kerja yang saling peduli antara karyawan dalam pengambilan keputusan. Serta lingkungan kerja yang saling memikirkan orang lain dalam setiap pengambilan keputusan. Dengan kondisi tersebut karyawan akan merasa memiliki kedekatan dengan organisasinya. Karena setiap karyawan akan memikirkan kesejahteraan orang lain dalam pembuatan keputusan mereka. Kedekatan pada organisasi menciptakan keterikatan antara karyawan dan organisasinya dimana dia akan membuat keputusan dengan memikirkan kesejahteraan organisasinya.

Keterikatan dan ketergantungan antara karyawan terdahap organisasi. Menjadikan karyawan merasa semua masalah yang ada di organisasi akan menjadi masalah bagi karyawan itu sendiri. Yaitu ketika organisasi mengalami kemunduran tentu karyawan juga akan mengalami hal tersebut. Di saat seperti ini karyawan akan memiliki rasa tanggung jawab yang besar. Kemunduran dalam organisasi dapat berdampak besar untuk karyawan, seperti bonus yang tidak keluar, gaji yang terlambat, bahkan dapat berupa pemecatan. Oleh karena itu karyawan akan semaksimal mungkin bekerja dengan baik, karena kehidupan mereka tergantung dari organisasi tersebut. 
Hal tersebut juga di dukung dengan riset Filipova (2011) yang menemukan bahwa caring ethical climate memiliki pengaruh positif terhadap komitmen organisasi. Swasto (2014) Menunjukkan bahwa hubungan antara komitmen organisasi dan kinerja karyawan adalah positif.

Berdasarkan pemikiran diatas, maka hubungan Caring climate, kinerja karyawan, dan komitmen organisasi dapat dirumuskan dalam hipotesis berikut:

\section{$\mathrm{H}_{2 \mathrm{~b}}$ : Caring climate memiliki pengaruh yang signifikan terhadap kinerja karyawan melalui peran mediasi komitmen organisasi.}

\section{Kepuasan Kerja, Komitmen Organisasi dan Kinerja}

Sikap positif yang dimiliki karyawan terhadap pekerjaannya, yang timbul berdasarkan penilaian terhadap situasi kerja. Penelitian ini kepuasan kerja berarti persepsi responden mengenai untuk tetap bekerja dan kepuasan terhadap pekerjaannya. Perasahaan responden mengenai seberapa besar keinginannya untuk berhenti dari pekerjaannya saat ini, dan perasahaannya mengenai seberapa puas dengan pekerjaan yang saat ini dia lakukan. Perasaan puas karyawan terhadap pekerjaan yang setiap hari dia lakukan dan kerjakan. Dan keinginan responden untuk tetap bekerja di organisasi tersebut.

Komitmen organisasi dalam penelitian ini adalah persepsi responden mengenai keterikatannya dan ketergantungannya dengan organisasi. Dengan adanya sifat ketergantungan dari karyawan terhadap organisasi serta keterikatannya. Hal ini akan membuat karyawan selalu melakukan yang terbaik untuk organisasi. Karena dengan adanya sifat ketergantungan apabila organisasi mengalami masalah maka karyawan juga akan mendapat masalah yang sama. Serta karena karyawan memiliki keterikan terhadap organisasi maka dia akan berusaha sebaik mungkin untuk membuat organisasi yang stabil dan nyaman untuk dia bekerja.

Sedangkan kinerja karyawan merupakan hasil kerja secara kualitas maupun kuantitas yang dicapai oleh seseorang dalam melaksanakan tugas yang diberikan kepadanya sesuai dengan standar atau kriteria yang telah ditetapkan. Dalam penelitian ini persepsi responden mengenai seberapa baik hasil penilaian kinerja menurut responden, menurut hasil penilaian kinerja oleh atasan dan oleh rekan kerja.

Saat karyawan memiliki perasaan puas terhadap pekerjaan yang setiap hari dia lakukan dan kerjakan. Dan keinginan responden untuk tetap bekerja di organisasi tersebut. Karyawan mendapatkan hal yang dia inginkan dari organisasi tersebut. Sehingga karyawan merasa puas dengan pekerjaannya dan organisasinya. Mereka merasa ingin tetap bekerja di organisasi ini dan menciptakan ikatan antara karyawan terhadap organisainya. Perasaan puas juga akan meningkatkan ketergantungan antara karyawan terhadap organisasinya.

Dengan adanya keterikatan dan ketergantungan karyawan dan organisasi. Semua masalah yang ada di organisasi akan menjadi masalah bagi karyawan itu sendiri. Dimana saat perusahaan mengalami kebrangkutan tentu karyawan juga kan mendapat masalah. Di saat seperti ini karyawan akan memiliki rasa tanggung jawab yang besar. Masalah yang di dapat mulai dari pengurangan gaji hingga pemecatan. Oleh karena itu karyawan akan sebisa mungkin bekerja dengan baik, karena kehidupan mereka tergantung dari organisasi tersebut.

Hayati dan Caniago (2014) menyatakan adanya hubungan signifikan dan positif antara kepuasan kerja dengan komitmen organisasi. Huang et al. (2012) Menunjukkan bahwa kepuasan kerja akan mampu meningkatkan komitmen organisasional. Swasto (2014) menemukan komitmen organisasi dan kinerja karyawan berhubungan positif.

Berdasarkan pemikiran diatas hubungan kepuasan kerja, komitmen organisasi, dan kinerja karyawan dapat dirumuskan dalam hipotesis berikut:

\section{$\mathrm{H}_{3}$ : Kepuasan kerja memiliki pengaruh yang signifikan terhadap kinerja karyawan melalui peran mediasi komitmen organisasi.}




\section{Kerangka Pikir}

Gambar 1 menampilkan hubungan-hubungan antara variabel-variabel yang menjadi fokus penelitian dan yang telah dinyatakan dalam hipotesis penelitian.

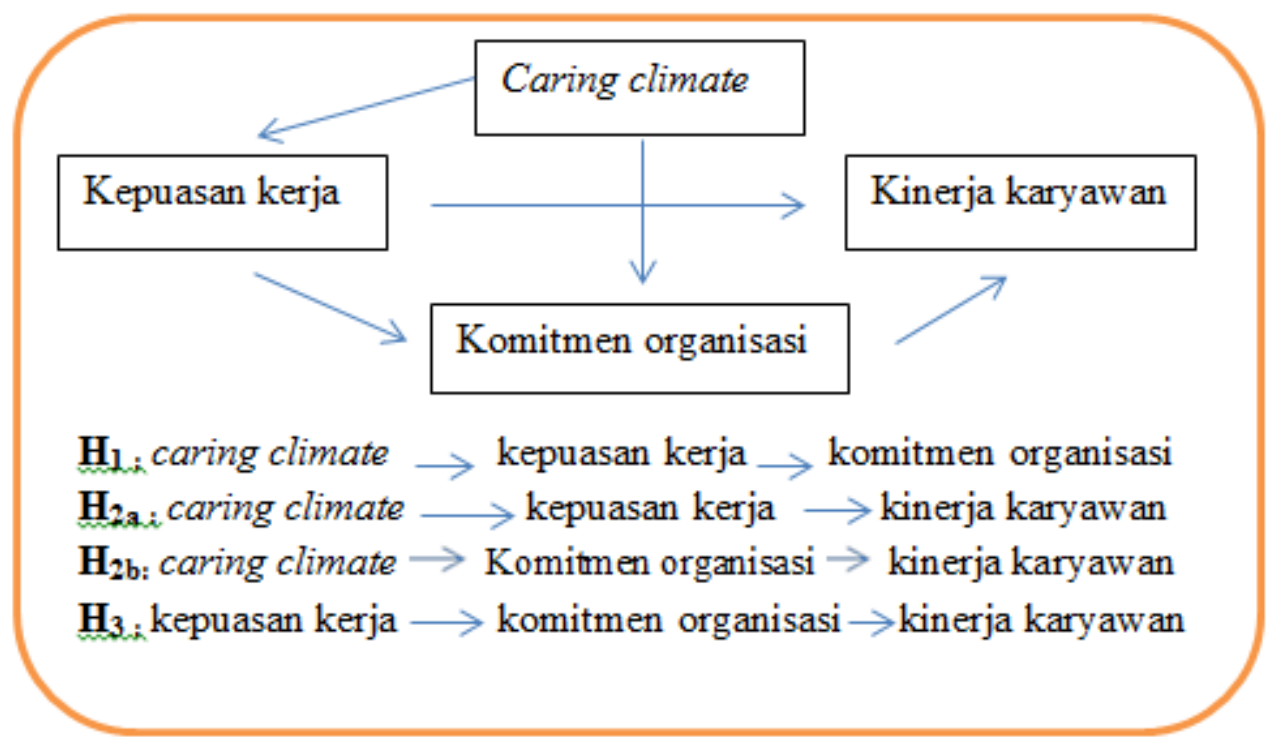

\section{Gambar 1. Kerangka penelitian}

\section{METODE PENELITIAN}

\section{Populasi dan sampel}

Populasi yaitu sekelompok orang, kejadian atau gejala sesuatu yang mempunyai karaktristik tertentu. Populasi dalam penelitian ini adalah seluruh karyawan Universtias Katolik Soegijapranata yang berjumlah 448 orang yang terdiri dari 212 tenaga kerja kependidikan dan 236 tenaga pengajar. Sampel merupakan bagian dari populasi yang menjadi perhatian peneliti. Pengambilan jumlah sampel dilakukan dengan menggunakan rumus Slovin untuk mendapatkan batas minimum.

$$
n=\frac{N}{1+N e^{2}}
$$

Keterangan:

$\mathrm{n}=$ ukuran sampel

$\mathrm{N}=\quad$ ukuran populasi

e $=$ kelonggaran ketidaktelitian karena kesalahan pengambilan sampel yang dapat ditolerir $(10 \%)$

jumlah sampel dalam penelitian ini dihitung sebagai berikut :

$$
\begin{aligned}
& n=\frac{448}{1+448(10 \%)^{2}} \\
& =81
\end{aligned}
$$

Berdasarkan perhitungan tersebut jumlah minimal sampel yang di ambil adalah 81 responden. Peneliti melakukan penyebaran kuesioner di Universtias Katolik Soegijapranata Semarang dengan jumlah karyawan 448 orang. Penyebaran dilakukan ke 139 karyawan Universitas 
Katolik Soegijapranata Semarang. Dari 139 kuesioner tersebut terdapat 96 kuesioner yang kembali dan 43 kuesioner yang tidak kembali. Sehingga jumlah sampel pada penelitian ini berjumlah 96, tetapi pada pengolahan sampel dieliminasi 10 responden karena mempengaruhi fit model penelitian. Tabel 1 menyajikan prosedur pemilihan sampel. Jumlah responden yang digunakan dalam penelitian ini 86 responden.

\section{Tabel 1. Sampel penelitian}

\begin{tabular}{lll}
\hline No & Keterangan & Jumlah \\
\hline 1 & Penyebaran kues tenaga kependidikan & 51 \\
2 & Penyebaran kues tenaga pengajar & 35 \\
3 & Eliminasi data & $(10)$ \\
4 & Jumlah data di olah & 86 \\
\hline
\end{tabular}

\section{Pengukuran variabel \\ Kinerja karyawan}

Kinerja karyawan dalam penelitian ini memiliki pengertian persepsi responden mengenai seberapa baik hasil penilaian kinerja menurut responden, menurut hasil penilaian kinerja oleh atasan dan oleh rekan kerja. Kinerja karyawan menggunakan instrumen dari (Fu dan Deshpande, 2014). Dan di ukur menggunakan skala linkert 1 sampai 5, dimana semakin mendekati angka 5 persepsi responden mengenai seberapa baik hasil penilaian kinerja mereka, akan sangat baik sedangkan mendekati angka 1 akan sangat buruk.

\section{Caring climate}

Caring climate merupakan persepsi responden mengenai pertimbangan kesejahteraan untuk setiap orang dalam organisasi yang digunakan saat membuat keputusan. Caring climate menggunakan intrumen dari (Fu dan Deshpande,2014). Di ukur menggunakan skala linkert 1 sampai 5, dimana semakin mendekati angka 5 kesejahteraan orang lain semakin menjadi pertimbangan orang lain dalam membuat keputusan sedangkan semakin mendekati angka 1 berarti kesejahteraan orang lain tidak menjadi pertimbangan dalam membuat keputusan.

\section{Komitmen organisasi}

Komitmen organisasi dalam penelitian merupakan persepsi responden mengenai keterikatannya terhadap organisasi serta memberikan yang terbaik untuk organisasi. Komitmen organisasi menggunakan instrumen dari (Thomas, 2013). Di ukur menggunakan skala linkert 1 sampai 5, dimana semakin mendekati angka 5 responden sangat memiliki keterikatan dan memberikan yang terbaik untuk organisasi, sedangkan semakin mendekati angka 1 responden sangat tidak terikat dengan organisasinya. Terdapat 6 pertanyaan yang bersifat negatif sehingga perlu dilakukan pembalikan nilai dalam setiap jawabanya.

\section{Kepuasan kerja}

Kepuasan kerja merupakan persepsi responden mengenai untuk tetap bekerja dan kepuasan terhadap pekerjaannya. Kepuasan kerja menggunakan instrumen dari ( $\mathrm{Fu}$ and Deshpande,2014). Di ukur menggunakan skala linkert 1 sampai 5, semakin mendekati angka 5 responden sangat puas terhadap pekerjaanya, sedangkan mendekati angka 1 responden sangat tidak puas terhadap pekerjaannya. Pertanyaan no 1 bersifat negatif sehinga perlu di lakukan pembalikan dalam penilaiannya yang di berikan oleh responden. 


\section{HASIL DAN PEMBAHASAN}

Uji normalitas data dan uji realibilitas dilakukan sebelum melakukan uji hipotesis. Tabel 2 menyajikan hasil pengujian normalitas, validitas dan realibilitas. Uji normalitas menggunakan AMOS yang dapat diketahui dari nilai skewness dan kurtoris. Pengujian validitas bertujuan untuk mengukur setiap indikator yang digunakan dalam penelitian ini. Jika nilai standardized loading estimate sama dengan 0.50 atau lebih, maka indikator tersebut dinyatakan valid. Terdapat 10 indikator yang tidak valid sehingga harus dibuang dari analisis. Indikator yang dibuang yaitu kepusan kerja 1, komitmen organisasi 15, 12, 11, 10, 9, $7,5,4,3$, sehingga hanya terdapat 12 indikator yang valid.

Tabel 2. Uji Normalitas, Validitas, dan Realibilitas

\begin{tabular}{|c|c|c|c|c|c|}
\hline No & Variabel & $\begin{array}{l}\text { Konstruk } \\
\text { reliabilitas }\end{array}$ & Estimasi & $\begin{array}{c}\text { Goodness } \\
\text { Of Fit }\end{array}$ & Normalitas \\
\hline 1 & Kepuasan Kerja & 0.763 & & & \\
\hline 2 & Komitmen Organisasi & 0.818 & & & \\
\hline 4 & Kinerja & 0.791 & & & \\
\hline 5 & KK_3 & & .854 & & \\
\hline 6 & KK_2 & & .849 & & \\
\hline 7 & JP_1 & & 637 & & \\
\hline 8 & JP_2 & & .788 & & \\
\hline 9 & JP_3 & & .811 & & \\
\hline 10 & KO_14 & & .654 & & \\
\hline 11 & KO_13 & & .569 & & \\
\hline 12 & KO_8 & & .638 & & \\
\hline 13 & KO_6 & & .666 & & \\
\hline 14 & KO_2 & & .679 & & \\
\hline 15 & KO_1 & & .554 & & \\
\hline 16 & Caring Climate & & & & \\
\hline 17 & Chi Square P & & & 0,055 & \\
\hline 18 & CMIN/DF & & & 1,338 & \\
\hline 19 & RMSEA & & & 0,063 & \\
\hline 20 & CFI & & & 0,963 & \\
\hline 21 & IFI & & & 0,964 & \\
\hline 23 & PNFI & & & 0,660 & \\
\hline 24 & PGFI & & & 0,572 & \\
\hline 25 & Multivariate & & & & 2.620 \\
\hline
\end{tabular}

Sumber : Data primer yang diolah (2019)

Pengujian reliabilitas digunakan untuk menunjukan adanya stabilitas skor yang diperoleh dari setiap responden. Contruct Reliability 0.70 atau lebih menunjukkan reliabilitas yang baik, sedangkan reliabilitas $0.60-0.70$ masih dapat diterima dengan syarat validitas indikator dalam mode baik (Gozhali 2017:144). Dari Tabel 2 dapat dilihat bahwa setiap indikator sudah memenuhi syarat reliabilitas. Ini dibuktikan dengan nilai construct reliability masing-masing indikator yang lebih dari 0.70. Sehingga setiap indikator menunjukan adanya stabilitas skor yang diperoleh dari setiap responden. 


\section{Deskriptif statistik}

Peneliti menggunakan uji beda rata-rata untuk mendeskripsikan dan mengelompokan berdasarkan demografi yang telah ditentukan. Range yang digunakan untuk mendeskripsikan setiap variabel menggunakan perhitungan di bawah ini.

Skor Maksimal $=$ Skor 5

Skor Minimal $=$ Skor 1

Bobot nilai indeks:

$$
\begin{aligned}
\text { Interval } & =\frac{\text { Max-Min }}{k} \\
& =\frac{5-1}{2}=2
\end{aligned}
$$
1. $1-3$
: Rendah
2. $3,01-5 \quad$ : Tinggi
3. P-value : $0,1(10 \%)$

\begin{tabular}{|c|c|c|c|c|c|c|c|c|c|c|c|}
\hline \multirow[t]{2}{*}{ Keterangan } & \multirow[t]{2}{*}{ Jumlah } & \multicolumn{2}{|c|}{$\begin{array}{c}\text { Kinerja } \\
\text { Karyawan }\end{array}$} & \multicolumn{3}{|c|}{ Caring climate } & \multicolumn{2}{|c|}{$\begin{array}{c}\text { Kepuasan } \\
\text { Kerja }\end{array}$} & \multicolumn{3}{|c|}{$\begin{array}{l}\text { Komitmen } \\
\text { Organisasi }\end{array}$} \\
\hline & & $\begin{array}{l}\text { Rata- } \\
\text { Rata }\end{array}$ & $\begin{array}{c}\text { Hasil } \\
\text { Uji } \\
\text { Beda }\end{array}$ & $\begin{array}{l}\text { Rata- } \\
\text { Rata }\end{array}$ & \multicolumn{2}{|c|}{$\begin{array}{c}\text { Hasil Uji } \\
\text { Beda }\end{array}$} & $\begin{array}{l}\text { Rata- } \\
\text { Rata }\end{array}$ & $\begin{array}{c}\text { Hasil } \\
\text { Uji } \\
\text { Beda }\end{array}$ & $\begin{array}{l}\text { Rata- } \\
\text { Rata }\end{array}$ & \multicolumn{2}{|c|}{$\begin{array}{cc} & \text { Hasil } \\
\text { Uji } \\
\text { Beda } \\
\end{array}$} \\
\hline \multirow[t]{2}{*}{ Jenis Kelamin } & Laki-laki & 49 & 4,14 & 0,029 & 4,63 & 0,009 & 4,16 & 0,048 & & 4,39 & 0,006 \\
\hline & Perempuan & 37 & 4,91 & & 4,32 & & 3,89 & & & 4,13 & \\
\hline \multirow[t]{2}{*}{ Pekerjaan } & $\begin{array}{c}\text { Tenaga } \\
\text { pengajar }\end{array}$ & 35 & 4,05 & 0,885 & 4,54 & 0,551 & 4,13 & 0.320 & & 4,28 & 0,924 \\
\hline & $\begin{array}{c}\text { Tenaga } \\
\text { kependidikn }\end{array}$ & 51 & 4,03 & & 4,47 & & 3,99 & & & 4,29 & \\
\hline \multirow[t]{3}{*}{ Umur } & $20-35$ th & 29 & 4,05 & 0,994 & 4,45 & 0,516 & 4,05 & 0,578 & & 4,39 & 0,237 \\
\hline & $36-50$ th & 36 & 4,04 & & 4,47 & & 4,11 & & & 4,26 & \\
\hline & $51-63$ th & 21 & 4,03 & & 4,62 & & 3,93 & & & 4,17 & \\
\hline \multirow[t]{3}{*}{ Lama bekerja } & 0-10 th & 38 & 4,01 & 0,858 & 4,45 & 0,686 & 4,07 & 0,942 & & 4,38 & 0,221 \\
\hline & $11-25$ th & 32 & 4,05 & & 4,56 & & 4,05 & & & 4,19 & \\
\hline & $26-35$ th & 16 & 4,08 & & 4,50 & & 4,00 & & & 4,24 & \\
\hline \multirow[t]{5}{*}{ Tingkat pendidikan } & SMA & 18 & 3,99 & 0,140 & 4,44 & 0,629 & 4,03 & 0,103 & & 4,28 & 0,039 \\
\hline & D3 & 8 & 3,67 & & 4,38 & & 3,50 & & & 3,86 & \\
\hline & S1 & 24 & 4,17 & & 4,42 & & 4,14 & & & 4,43 & \\
\hline & S2 & 23 & 4,07 & & 4,61 & & 4,17 & & & 4,29 & \\
\hline & S3 & 13 & 4,02 & & 4,62 & & 4,00 & & & 4,27 & \\
\hline
\end{tabular}

Tabel 3. Deskriptif Statistik

Dari Tabel 3 dapat dilihat deskipsi dari masing-masing responden yang memiliki data dari 86 responden, yang terdiri dari 49 laki- laki dan 37 perempuan dengan pekerjaan 35 tenaga pengajar dan 51 tenaga kependidikan. Serta memiliki usia kurang 36 tahun sebanyak 29 responden, 36 - 50 tahun sebanyak 36 responden dan diatas 51 tahun sebanyak 21 responden. Dengan proporsi lama bekerja kurang dari 11 tahun sebanyak 38 responden, 1125 tahun sebanyak 32 responden dan diatas 25 tahun sebanyak 16 responden. Responden juga terbagi berdasarkan tingkat pendidikan yang terdiri dari SMA/sederajat 18 responden, D3 8 responden, S1 24 responden, S2 23 responden dan S3 13 responden.

Demografi jenis kelamin, menunjukan bahwa semua variabel memiliki beda signifikan $<0,1$. Hasilnya ada perbedaan rata-rata antara responden laki-laki dan perempuan mengenai kinerja karyawan, caring climate, kepuasan kerja, dan komitmen organisasi. Artinya jenis kelamin menjadi pembeda persepsi laki-laki dan perempuan terhadap rata-rata kinerja 
karyawan, caring climate, kepuasan kerja, dan komitmen organisasi.

Demografi tingkat pendidikan, menunjukan hanya variabel komitmen organisasi yang memiliki beda signifikan $<0,1$. Sehingga ada perbedaan rata-rata antara responden tingkat pendidikan SMA, D3, S1, S2 dan S3 mengenai komitmen organiasi. Artinya tingkat pendidikan menjadi pembeda persepsi terhadap komitmen organisasi.

\section{Pengujian Hipotesis}

Tabel 4 menunjukan bahwa caring climate memiliki pengaruh terhadap kepuasan kerja dengan nilai $p$-value sebesar 0,042. Selain itu kepuasan kerja memiliki pengaruh terhadap komitmen organisasi sebesar 0,000. Artinya caring climate memiliki pengaruh terhadap komitmen organisasi dengan peran mediasi kepuasan kerja. Sehingga hipotesis 1 caring climate memiliki pengaruh yang signifikan terhadap komitmen organisasi melalui peran mediasi kepuasan kerja diterima.

Tabel 4. Hasil Uji hipotesis

\begin{tabular}{lllllll}
\hline & & & Estimate & S.E. & C.R. & P \\
\hline KK & $<---$ & Cc & .290 & .143 & 2.038 & 0.042 \\
KO & $<--$ & KK & .338 & .081 & 4.162 & 0,000 \\
KO & $<---$ & Cc & .196 & .079 & 2.473 & 0.013 \\
JP & $<---$ & KK & .318 & .093 & 3.423 & 0,000 \\
JP & $<---$ & KO & .168 & .138 & 1.223 & 0.221 \\
\hline
\end{tabular}

Sumber : Data primer yang diolah (2019)

Caring climate terhadap kepuasan kerja memberikan pengaruh yang positif. Artinya dengan lingkungan kerja yang saling memiliki kepedulian antara karyawan serta mempertimbangkan kesejahteraan setiap orang dalam organisasi saat mengambil keputusan. Menciptakan lingkungan kerja yang nyaman untuk setiap karyawan. Karena lingkungan kerja yang nyaman karyawan menjadi ingin tetap bekerja dan puas terhadap pekerjaan yang saat ini sedang mereka lakukan.

Kepuasan kerja dalam penelitian ini merupakan persepsi responden mengenai keinginan untuk tetap bekerja dan puas dengan pekerjaannya. Kepuasan kerja memiliki pengaruh terhadap komitmen organisasi. Hal ini membuktikan saat karyawan telah merasa puas dengan yang dia dapatkan dari organisasi serta semua kebutuhannya sudah tercukupi di organisasi tersebut. Karyawan menjadi nyaman di organisasi dan tidak ingin meninggalkan organisasi tersebut. Artinya saat karyawan memiliki perasaan puas dengan pekerjaannya mereka juga menciptakan ikatan antara karyawan dan organisasinya.

Hasil ini mendukung penelitian yang dilakukan oleh Okpara dan Wynn (2012) yang berjudul The impact of ethical climate on job satisfaction, and commitment in Nigeria. Dan penelitian (Saeed dan Rizwan, 2014) yang bejudul The relationship of Turnover intention with job satisfaction, job performance, Leader member exchange, Emotional intelligence and organizational commitment

Tabel 4 juga menunjukkan bahwa kepuasan kerja memiliki pengaruh terhadap kinerja karyawan sebesar 0,000. Artinya caring climate memiliki pengaruh mediasi kepuasan kerja terhadap kinerja karyawan. Sehingga hipotesis $2_{\mathrm{a}}$ caring climate memiliki pengaruh yang signifikan terhadap kinerja karyawan melalui peran mediasi kepuasan kerja diterima. Caring climate terhadap kepuasan kerja memberikan pengaruh yang positif. Artinya dengan lingkungan kerja yang saling memiliki kepedulian antara karyawan serta mempertimbangkan kesejahteraan setiap orang dalam organisasi saat mengambil keputusan. Menciptakan lingkungan kerja yang nyaman untuk setiap karyawan. Karena lingkungan kerja yang nyaman 
karyawan menjadi ingin tetap bekerja dan puas terhadap pekerjaan yang saat ini sedang mereka lakukan.

Kepuasan kerja berpengaruh terhadap kinerja karyawan. Sehingga kepuasan kerja menjadi penting untuk meningkatkan kinerja karyawan. Karena saat karyawan merasa puas dengan pekerjaan mereka dan keinginan untuk tetap bekerja di organisasi tersebut akan menciptakan perasaan cinta terhadap pekerjaan mereka. Membuat karyawan melakukan pekerjaan mereka dengan sepenuh hati dan menyelesaikan pekerjaan mereka sesuai target yang telah ditentukan. Mereka melakukannya dengan senang hati tanpa ada perasaan terbebani oleh pekerjaan yang mereka lakukan saat ini.

Hal ini mendukung penelitian (Indrawati, 2013) yang bejudul Pengaruh Kepuasan Kerja Terhadap Kinerja Karyawan Dan Kepuasan Pelanggan Pada Rumah Sakit Swasta Di Kota Denpasar. Okpara dan Wynn (2012) yang berjudul The impact of ethical climate on job satisfaction, and commitment in Nigeria.

Hasil yang disajikan pada tabel 4 juga menunjukkan bahwa caring climate memiliki pengaruh terhadap komitmen organisasi sebesar 0,013, tetapi komitmen organisasi tidak memiliki pengaruh terhadap kinerja karyawan. Karena nilai sig komitmen organisasi terhadap kinerja karyawan sebesar 0,221 sedangkan nilai sig yang di syaratkan $<0,1$ (10\%) oleh karena itu komitmen organisasi tidak memiliki pengaruh terhadap kinerja karyawan. Artinya caring climate tidak memiliki pengaruh terhadap kinerja karyawan melalui peran mediasi komitmen organisasi. Hipotesis $2_{\mathbf{b}}$ caring climate memiliki pengaruh yang signifikan terhadap kinerja karyawan melalui peran mediasi komitmen organisasi tidak diterima.

Caring climate terhadap komitmen organisasi memiliki pengaruh. Caring climate menciptakan lingkungan kerja yang saling peduli antara karyawan. Lingkungan kerja yang saling memikirkan orang lain dalam pengambilan keputusan organisasi. Kondisi tersebut membuat karyawan memiliki kedekatan dengan organisasinya. Kedekatan pada organisasi menciptakan keterikatan antara karyawan dan organisasinya serta karyawan berkeinginan memberikan yang terbaik untuk organisasi.

Sedangkan komitmen organisasi tidak memiliki pengaruh terhadap kinerja karyawan. Ternyata meskipun karyawan memiliki keterikatan terhadap organisasi tidak menjadikan karyawan memiliki kinerja yang baik dalam organisasi tersebut. Selain itu di Universtias Katolik Soegijapranata Semarang hanya menerapkan standart minimal untuk penilaian kinerja tenaga pengajar dan tenaga kependidikan. Sehingga karyawan tidak memiliki ekspetasi untuk standart maksimal dari penilaian kinerja mereka. Sehingga karyawan hanya memiliki keterikatan dengan organisasi tanpa ingin bekerja secara maksimal dan memberikan yang terbaik untuk organisasinya.

Hasill ini mendukung penelitian yang dilakukan oleh Waterkamp et al. (2017) dalam penelitian yang berjudul Pengaruh Profesionalisme, Komitmen Organisasi Dan Kepuasan Kerja Terhadap Kinerja Karyawan Pada PT. Bank Rakyat Indonesia (Persero) Cabang Manado yang menyatakan bahwa komitmen organisasional secara parsial tidak berpengaruh signifikan terhadap kinerja karyawan dengan nilai sig.t $(0,368)>a=0,05$.

Tabel 4 juga menunjukan bahwa kepuasan kerja memiliki pengaruh terhadap komitmen organisasi sebesar 0,000 , sedangkan komitmen organisasi tidak memiliki pengaruh signifikan terhadap kinerja karyawan karena memiliki nilai sig sebesar 0,221. Nilai sig komitmen organisasi terhadap kinerja karyawan sebesar 0,221, dimana nilai tersebut melebihi nilai sig yang ditentukan sebesar $<0,1(10 \%)$ oleh karena itu komitmen organisasi tidak memiliki pengaruh terhadap kinerja karyawan. Artinya kepuasan kerja tidak memiliki pengaruh terhadap kinerja karyawan dengan mediasi komitmen organisasi. Jadi hipotesis 3 Kepuasan kerja memiliki pengaruh yang signifikan terhadap kinerja karyawan melalui peran mediasi komitmen organisasi tidak di terima. 
Kepuasan kerja memiliki pengaruh terhadap komitmen organisasi. Hal ini membuktikan saat karyawan telah merasa puas dengan yang dia dapatkan dari organisasi serta semua kebutuhannya sudah tercukupi di organisasi tersebut. Karyawan menjadi nyaman di organisasi dan tidak ingin meninggalkan organisasi tersebut. Artinya saat karyawan memiliki perasaan puas dengan pekerjaannya mereka juga menciptakan ikatan antara karyawan dan organisasinya.

Tetapi karyawan memiliki keterikatan terhadap organisasi tidak menjadikan karyawan memiliki kinerja yang baik dalam organisasi tersebut. Selain itu di Universtias Katolik Soegijapranata Semarang hanya menerapkan standart minimal untuk penilaian kinerja tenaga pengajar dan tenaga kependidikan. Sehingga karyawan tidak memiliki ekspetasi untuk standart maksimal dari penilaian kinerja mereka. Sehingga karyawan hanya memiliki keterikatan dengan organisasi tanpa ingin bekerja secara maksimal dan memberikan yang terbaik untuk organisasinya.

Hal ini mendukung penelitian yang dilakukan oleh Waterkamp et al. (2017) dalam penelitian yang berjudul Pengaruh Profesionalisme, Komitmen Organisasi Dan Kepuasan Kerja Terhadap Kinerja Karyawan Pada PT. Bank Rakyat Indonesia (Persero) Cabang Manado yang menyatakan bahwa komitmen organisasional secara parsial tidak berpengaruh signifikan terhadap kinerja karyawan dengan nilai sig.t $(0,368)>a=0,05$.

\section{Pembahasan}

Penelitian Fu dan Deshpande (2014) menunjukkan bahwa kinerja karyawan dipengaruhi caring climate, kepuasan kinerja, dan komitmen organisasi. Penelitian tersebut menggunakan sampel yang terdiri dari $43,7 \%$ responden laki-laki dan 56,3\% responden perempuan.

Tabel 5. Perbandingan Dengan Penelitian Fu dan Deshpande (2014)

\begin{tabular}{|c|c|c|}
\hline & Penelitian saat ini & Penelitian sebelumnya \\
\hline \multirow{2}{*}{$\begin{array}{l}\text { Proporsi } \\
\text { gender }\end{array}$} & Laki-laki $57 \%$ & Laki-laki 43,7 \% \\
\hline & Perempuan $43 \%$ & Perempuan $56 \%$ \\
\hline \multirow[t]{5}{*}{ Hipotesis 1} & Caring climate memiliki & Caring climate memiliki \\
\hline & pengaruh tehadap & pengaruh \\
\hline & komitmen & komitmen \\
\hline & melalui peran media & melalui peran media \\
\hline & kepuasan kerja. & kepuasan kerja. \\
\hline \multirow[t]{5}{*}{ Hipotesis $2 \mathrm{a}$} & Caring & Caring climate \\
\hline & berpengaruh & berpengaruh terhadap \\
\hline & kinerja karyawan melalui & kinerja karyawan melalui \\
\hline & peran mediasi kepuasan & peran mediasi kepuasan \\
\hline & kerja. & kerja. \\
\hline \multirow[t]{5}{*}{ Hipotesis $2 \mathrm{~b}$} & Caring & Caring \\
\hline & berpengaruh terhadap & berpengaruh terhadap \\
\hline & kinerja karyawan melalui & kinerja karyawan melalui \\
\hline & peran media komitmen & peran media komitmen \\
\hline & organisasi. & organisasi. \\
\hline \multirow[t]{5}{*}{ Hipotesis 3} & Kepuasan kerja tidak & Kepuasan \\
\hline & berpengaruh terhadap & berpengaruh terhadap \\
\hline & kinerja karyawan melalui & kinerja karyawan melalui \\
\hline & peran media komitmen & peran media komitmen \\
\hline & organisai. & organisai. \\
\hline
\end{tabular}

Sumber : Fu dan Deshpande, 2014 
Sedangkan penelitian ini menggunakan sampel yang terdiri dari $57 \%$ responden laki-laki dan $43 \%$ responden perempuan. Sehingga perlu dilakukan perbandingan antara penelitian sebelumnya dan penelitian saat ini, dikarenakan terdapat perbedaan karakteristik sampel khususnya dalam jumlah responden laki-laki dan perempuan yang berbeda. Tabel 5 menjelaskan lebih detail perbedaan hasil yang diperoleh.

Dengan adanya jumlah proporsi gender yang berbeda antara penelitian sebelumnya dan penelitian saat ini, memberikan hasil yang berbeda dimana pada penelitian sebelumnya kepuasan kerja tidak berpengaruh terhadap kinerja karyawan. Tetapi pada penelitian saat ini kepuasan kerja berpengaruh terhadap kinerja karyawan. Selain itu pada penelitian sebelumnya komitmen organisasi berpengaruh terhadap kinerja karyawan. Tetapi pada penelitian saat komitmen organisasi tidak berpengaruh terhadap kinerja karyawan. Dengan hasil yang berbeda dengan penelitian sebelumnya.

Gender dalam penelitian ini memberikan perbedaan. Dimana saat proporsi gender lakilaki lebih banyak maka kepuasan kerja akan berpengaruh signifikan terhadap kinerja karyawan, karena laki-laki memiliki karakteristik sebagai pengambil inisiatif dalam bekerja, dan pengarah kemajuan di dalam organisasi serta lebih memberikan dorongan pada rekan kerja. Dengan karakteristik laki-laki sebagai pemberi dorongan pada rekan kerjanya maka karyawan dalam organisasi akan bekerja dengan baik, sehingga karyawan akan memiliki kepuasan terhadap pekerjannya dan keinginan untuk tetap bekerja. Sedangkan proporsi gender laki-laki yang lebih banyak membuat komitmen organisasi tidak berpengaruh signifikan terhadap kinerja karyawan. Karena laki-laki memiliki karakteristik sosial yang bersifat egosentris, sehingga lebih mengandalkan dirinya sendiri tanpa memiliki keterikatan terhadap organisasi. Dengan tidak memiliki keterikatan terhadap organisasi, maka laki-laki tidak dapat memberikan yang terbaik untuk organisasi tersebut.

Caring climate terhadap kepuasan kerja memberikan pengaruh yang positif. Artinya dengan lingkungan kerja yang saling memiliki kepedulian antara karyawan serta mempertimbangkan kesejahteraan setiap orang dalam organisasi saat mengambil keputusan. Menciptakan lingkungan kerja yang nyaman untuk setiap karyawan. Karena lingkungan kerja yang nyaman karyawan menjadi ingin tetap bekerja dan puas terhadap pekerjaan yang saat ini sedang mereka lakukan.

Kepuasan kerja dalam penelitian ini merupakan persepsi responden mengenai keinginan untuk tetap bekerja dan puas dengan pekerjaannya. Kepuasan kerja memiliki pengaruh terhadap komitmen organisasi. Hal ini membuktikan saat karyawan telah merasa puas dengan yang dia dapatkan dari organisasi serta semua kebutuhannya sudah tercukupi di organisasi tersebut. Karyawan menjadi nyaman di organisasi dan tidak ingin meninggalkan organisasi tersebut. Artinya saat karyawan memiliki perasaan puas dengan pekerjaannya mereka juga menciptakan ikatan antara karyawan dan organisasinya.

Kepuasan kerja berpengaruh terhadap kinerja karyawan. Sehingga kepuasan kerja menjadi penting untuk meningkatkan kinerja karyawan. Karena saat karyawan merasa puas dengan pekerjaan mereka dan keinginan untuk tetap bekerja di organisasi tersebut akan menciptakan perasaan cinta terhadap pekerjaan mereka. Membuat karyawan melakukan pekerjaan mereka dengan sepenuh hati dan menyelesaikan pekerjaan mereka sesuai target yang telah ditentukan. Mereka melakukannya dengan senang hati tanpa ada perasaan terbebani oleh pekerjaan yang mereka lakukan saat ini.

Caring climate terhadap komitmen organisasi memiliki pengaruh. Caring climate menciptakan lingkungan kerja yang saling peduli antara karyawan. Lingkungan kerja yang saling memikirkan orang lain dalam pengambilan keputusan organisasi. Kondisi tersebut membuat karyawan memiliki kedekatan dengan organisasinya. Kedekatan pada organisasi menciptakan keterikatan antara karyawan dan organisasinya serta karyawan berkeinginan memberikan yang terbaik untuk organisasi. 
Tetapi komitmen organisasi tidak memiliki pengaruh terhadap kinerja karyawan. Keterikatan terhadap organisasi serta memberikan yang terbaik untuk organisasi. Ternyata meskipun karyawan memiliki keterikatan terhadap organisasi tidak menjadikan karyawan memiliki kinerja yang baik dalam organisasi tersebut. Selain itu di Universtias Katolik Soegijapranata Semarang hanya menerapkan standart minimal untuk penilaian kinerja tenaga pengajar dan tenaga kependidikan. Sehingga karyawan tidak memiliki ekspetasi untuk standart maksimal dari penilaian kinerja mereka. Sehingga karyawan hanya memiliki keterikatan dengan organisasi tanpa ingin bekerja secara maksimal dan memberikan yang terbaik untuk organisasinya.

Berdasarkan hasil uji amos kita dapat melihat bahwa carring climate menjadi penting untuk organisasi karena lingkungan kerja yang saling memikirkan orang lain dalam pengambilan keputusan organisasi akan mempengaruhi kepuasan, komitmen dan kinerja seseorang dalam organisasi tersebut. Sehingga penting bagi organisasi untuk menerapkan caring climate dalam organisasinya dan mempertahankannya untuk kelangsungan organisasi tersebut. Tetapi komitmen organisasi tidak dapat menjadi mediasi caring climate terhadap kinerja karyawan. Karena di Universtias Katolik Soegijapranata Semarang hanya menerapkan standart minimal untuk penilaian kinerja tenaga pengajar dan tenaga kependidikan. Sehingga karyawan tidak memiliki ekspetasi untuk standart maksimal dari penilaian kinerja mereka.

\section{SIMPULAN DAN SARAN}

\section{Simpulan}

Berikut adalah kesimpulan dalam penelitian ini.

1. Gender menjadi pembeda persepsi responden laki-laki dan perempuan terhadap caring climate, kinerja karyawan, kepuasan kerja dan komitmen organisasi

2. Caring climate berpengaruh terhadap komitmen organisasi melalui peran mediasi kepuasan kerja.

3. Caring climate berpengaruh terhadap kinerja karyawan melalui peran mediasi kepuasan kerja.

4. Caring climate tidak berpengaruh terhadap kinerja karyawan melalui peran mediasi komitmen organisasi

5. Kepuasan kerja tidak berpengaruh terhadap kinerja karyawan melalui peran mediasi komitmen organisasi

\section{Saran}

Penelitian ini hanya dilakukan di Universitas Katolik Soegijapranta sehingga hasil penelitian mungkin tidak dapat di interprestasikan untuk organisasi lain, karena masingmasing organisasi memiliki sistem organisasi yang berbeda. Universitas Katolik Soegijapranta menerapkan sistem organisasi yang bersifat kolegial. Dimana atasan dan bawahan dapat bertukar posisi. Hal ini mungkin berbeda dengan organisasi lain. Oleh karena itu, penelitian dengan topik yang sama perlu dilakukan agar generalisasi hasil penelitian dapat ditingkatkan.

\section{DAFTAR PUSTAKA}

Aftab, H., and W. Idrees. 2012. A Study of Job Satisfaction and IT's Impact on the Performance in the Banking Industry of Pakistan. International Journal of Business and Social Science 3(19): 174-180.

Filipova. A. A. 2011. Relationships Among Ethical Climates, Perceived Organizational 
Support, and Intent-to-Leave for Licensed Nurses in Skilled Nursing Facilities. Journal of Applied Gerontology 30(1): 44-66.

Fu. W., and S. P. Deshpande. 2014. The Impact of Caring Climate, Job Satisfaction, and Organizational Commitment on Job Performance of Employees in a China's Insurance Company. Journal of Business Ethics 124(2): 339-349.

Hayati, K., and I. Caniago. 2014. Islamic Work Ethic: The Role of Intrinsic Motivation , Job Satisfaction, Organizational Commitment and Job Performance. Procedia - Social and Behavioral Sciences 65(12): 1102-1106.

Huang, C., C. You. , and M. Tsai. 2012. A multidimensional analysis of ethical climate, job satisfaction, organizational commitment, and organizational citizenship behaviors. Nursing Ethics 19(4): 513-529.

Jaramillo, F., J.P. Mulki, and P. Solomon. 2017. The Role of Ethical Climate on Salesperson ' s Role Stress, Job Attitudes, Turnover Intention, and Job Performance. The Journal of Personal Selling and Sales Management 26(3): 271-282.

Saeed, I., and M. Rizwan. 2014. The relationship of Turnover intention with job satisfaction , job performance, Leader member exchange, Emotional intelligence and organizational commitment. International Journal of Learning \& Development 4(2): 2164-4063.

Ghozali, I. 2017. Model Persamaan Struktural Konsep dan Aplikasi dengan Program Amos 24 update bayesian SEM Edisi 7. (A. Tejokusumo, Ed.) (7 ed.). Semarang: Badan Penerbit Universitas Diponegoro Semarang.

Kartono, K. 1992. Psikologi Wanita (jilidl) (5 ed.). Bandung: penerbit mandar maju.

Indrawati, A. D. 2013. Pengaruh kepuasan kerja terhadap kinerja karyawan dan kepuasan pelanggan pada rumah sakit swasta di kota denpasar. Universitas Udayana, Bali. Di akses pada 17 September 2019, dari:

https://ojs.unud.ac.id/index.php/jmbk/article/view/6997/5246

Thomas, T. P. 2013. The Effect Of Personal Values, Organizational Values, And PersonOrganization Fit On Ethical Behaviors And Organizational Commitment Outcomes Among Substance Abuse Counselors: A Preliminary Investigation. The University of Iowa, Iowa. Di akses pada 23 September 2019, dari : https://ir.uiowa.edu/etd/4920/

Melina, T. C., and I. Ratnawati. 2012. Analisis Pengaruh Budaya Organisasi Dan Kepuasan Kerja Terhadap Komitmen Organisasional Dalam Meningkatkan Kinerja Karyawan (Studi Pada Pt. Sido Muncul Kaligawe Semarang). Universitas Stikubank, Semarang. Di akses pada 27 september 2019, dari

https://www.unisbank.ac.id/ojs/index.php/fe3/article/download/1740/650

Murty, W. A., and G. Hudiwinarsih. 2012. Pengaruh Kompensasi, Motivasi Dan Komitmen Organisasional Terhadap Kinerja Karyawan Bagian Akuntansi (Studi Kasus Pada 
Perusahaan Manufaktur Di Surabaya). STIE Perbanas Surabaya, Surabaya. Diakses pada 2 oktober 2019, dari https://doi.org/10.14414/tiar.v2i02.97

Okpara, J. O., and P. Wynn. 2012 . The impact of ethical climate on job satisfaction, and commitment in Nigeria. Journal of Management Development, 27(9), 935-950. https://doi.org/10.1108/02621710810901282

Ristadewi, S. 2011. Analisis Penilaian Kinerja Karyawan Pada Pt. Inti (Persero) Bandung. Universitas Widyatama, Bandung. Di akses pada 15 Oktober 2019, dari http://repository.widyatama.ac.id/xmlui/handle/123456789/4308

Swasto, B. 2014. Pengaruh motivasi kerja dan komitmen organisasional terhadap kinerja karyawan, 7(2), 1-9. Universitas Brawijaya, Malang. Di akses pada 20 Oktober 2019, dari http://administrasibisnis.studentjournal.ub.ac.id/index.php/jab/article/view/324

Tania, A., and M. E. Sutanto. 2013. Pengaruh Motivasi Kerja Dan Kepuasan Kerja Terhadap Komitmen Organisasional Karyawan Pt . Dai Knife Di Surabaya, 1(3). Universitas Kristen Petra, Surabaya. Di akses pada 22 Oktober 2019, dari http://repository.petra.ac.id/16260/

Waterkamp, C. I. A.,H. Tawas, and C. Mintardjo. 2017. Pengaruh Profesionalisme, Komitmen Organisasi Dan Kepuasan Kerja Terhadap Kinerja Karyawan Pada Pt. Bank Rakyat Indonesia (Persero) Cabang Manado. Universitas Sam Ratulangi, Manado. Di akses pada 30 Oktober 2019, dari https://ejournal.unsrat.ac.id/index.php/emba/article/view/17159 